\title{
THE 1996 ICCA JOURNAL AWARD
}

\author{
The Board of ICCA
}

\begin{abstract}
In 1992, a novel awald was instituted by the ICCA, the ICCA Journal Award The ICCA Journal Award is to be adjudicated to a tirst-time author for the best article in the ICCA Journal The first ICCA Journal Award (1993) covered the articles published in the issues Vol 15, No 2 up to and including Vol 16, No 1 Peter Jansen was the fisst winner of the ICCA Jounal Award Peter Jansen has been gianted the award for his article KQKR Awareness of a Fallible Opponent as published in Vol 15, No 3 pp 111-131 The winner of the second ICCA Journal Award was Christian Donninger for his atticle Null Move and Deep Search in Vol 16, No 3, pp 137143 The third ICCA Journal Award has been gianted to Bradley Kuszmaul for his article The StarTech Massively Parallel Chess Program in Vol 18, No 1, pp 3-19 The winner of the 1996 ICCA Journal Award was Michael Buro for his article Probcut An Effective Selective Extension of the $\alpha \beta$ Algorithm as published in Vol 18, No 2, pp 71-76
\end{abstract}

\section{MICHAEL BURO: A SCIENTIFIC BIOGRAPHY}

In the December 1996 issue of the Journal Michael Buro was announced as the winner of the 1996 ICCA Journal Award As an intrinsic part of the Award, a brief scientific biography of the winnei is published below

Michael Buro finished his studies of computer science and electrical engineering at RWTH Aachen (Rheinısche Westfalısche Technısche Hochschule), Germany in 1990, with a diploma thesis investigatıng technıques for partially solving the haltıng problem for Turıng machines At the end of 1990, he joined the knowledge-based systems group of Piofessor Kleine Buning at the University of Duisbuig (later Paderborn) as a research and teaching assistant Here, he first worked on resolution and SAT algorithms and organized a SAT competition in 1991 Inspired by the JAIR article by Lee and Mahajan on a statistical approach for learnıng parameters of evaluation functions, he decided to investigate learnıng approaches in game playıng which eventually led to his $\mathrm{Ph} \mathrm{D}$ thesis and to the computer program LOGISTELLO, which is still considered one of the top Othello programs in the world Since November 1995, he is workıng for NEC Research Institute in Princeton where he is involved in projects dealıng with multi agent learnıng systems and new approaches for searching game trees

\section{THE 1997 ICCA JOURNAL AWARD}

\author{
The Board of ICCA
}

The fitth ICCA Journal Award covers the articles published in the issues Vol 19, No 2 up to and including Vol 20, No 1 The winner will receive a hand-lettered certificate to this effect and will have a choice of any three volumes of the Journal's back issues The name of the winning author will also, of course, be published in the ICCA Journal with a short curriculum vitae if so desired The judges will be computerchess experts with proved expertise in technical writing The winner of the tifth ICCA Journal Award will be announced in Vol 20, No 4 